Portland State University

PDXScholar

7-11-1994

\title{
The Feminine as Salvific in Hildegard von Bingen's Letters
}

Marie Theresa Maurer

Portland State University

Follow this and additional works at: https://pdxscholar.library.pdx.edu/open_access_etds

Part of the German Language and Literature Commons Let us know how access to this document benefits you.

Recommended Citation

Maurer, Marie Theresa, "The Feminine as Salvific in Hildegard von Bingen's Letters" (1994). Dissertations and Theses. Paper 4860.

https://doi.org/10.15760/etd.6736

This Thesis is brought to you for free and open access. It has been accepted for inclusion in Dissertations and Theses by an authorized administrator of PDXScholar. Please contact us if we can make this document more accessible: pdxscholar@pdx.edu. 


\section{THESIS APPROVAL}

The abstract and thesis of Marie Theresa Maurer for the Master of Arts in

German were presented July 11,1994, and accepted by the thesis committee and the department.

COMMITTEE APPROVALS:

DEPARTMENT APPROVAL:

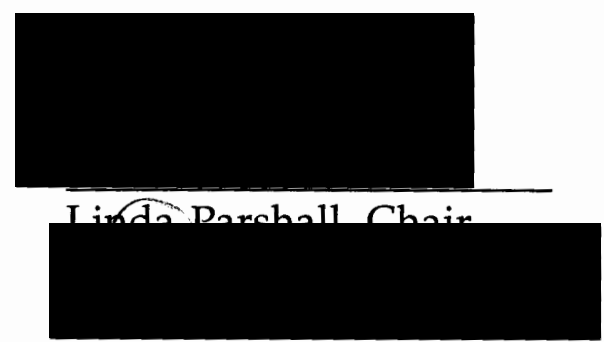

Louis Elteto

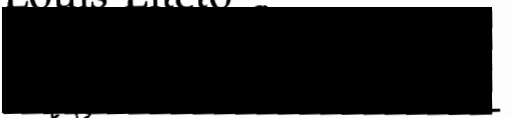

Steven Fuller

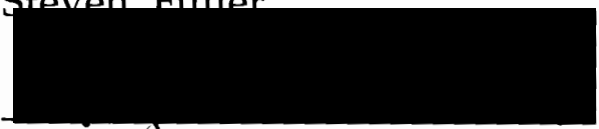

Marjorie Burns, Representative of the Office of Graduate Studies

Linda Parshall, Chair

Department of Foreign

Languages and Literatures

ACCEPTED FOR PORTLAND STATE UNIVERSITY BY THE LIBRARY

by

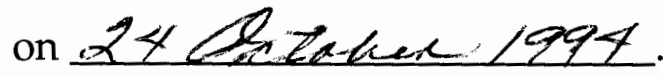


AN ABSTRACT OF THE THESIS OF Marie Theresa Maurer for the Master of Arts in German presented July 11, 1994.

Title: The Feminine as Salvific in Hildegard von Bingen's Letters

Hildegard alleged a spiritual connection with the physical world in her claim that she, a woman, was chosen by God to incarnate His Word on earth as Christ had done in the flesh years before. Woman, the embodiment of the feminine, was connected to the physical world in the medieval era. It was with this idea in mind that Hildegard attached an important significance to nature and the Virgin, seeing each as the ultimate expressions of the feminine divine on earth. However, included in the incarnation, according to Hildegard, was the Church itself along with the clergy, both men and women. In earth, in mankind, in all of nature, she saw a dimension of God, a dimension that found its expression uniquely in the world yet paralleled the God beyond this world.

Using Hildegard's letters in German translation, I will show how, in a patriarchal world of the 12th century, Hildegard emphasized the feminine as salvific as a means to establish a balance in the world, a balance that had been offset by the corrupt behavior of Church and State. I will preface this with a brief discussion of the era (p. 6). In Chapter II, I will focus first on how Hildegard saw the feminine manifested in the world and how, for various purposes, she expressed it in her letters. Secondly in Chapter II, by citing further examples in her letter, I will concentrate on how she saw a lack of feminine expression in the world and how she 
viewed the negative result of this lack. Finally in Chapter IV, I will show how she achieved the expression of this balance. In concluding my paper, I will consider whether she was successful in her efforts: Did she achieve, from others as well as from herself, the balance she sought or were her efforts in vain? 
THE FEMININE AS SALVIFIC

IN HILDEGARD VON BINGEN'S LETTERS

\author{
by \\ MARIE THERESA MAURER
}

A thesis submitted in partial fulfillment of the requirements for the degree of

\title{
MASTER OF ARTS
}

in

GERMAN

Portland State University

1994 


\section{Introduction}

When introduced to Hildegard von Bingen for the first time, I learned that her place in history was as one of Germany's first Christian visionaries along with Elizabeth of Schönau and Mechthild von Magdeburg. ${ }^{1}$ Since she wrote only in Latin and therefore did not make a contribution to the flowering of the German language as Mechthild von Magdeburg had done, I was left with the notion that Hildegard's fame lay exclusively in her mystical revelations. In the Vita, a biography of Hildegard's life composed by two monks of the twelfth century, Gottfried and Theodrich, Hildegard is remembered for her visionary gift as it surfaced in the very early stages of her life:

Denn schon in jungen Jahren zeigte sie eine frühe Unberührtheit, mit der sie allen fleischlichen Gelusten fremd zu sein schien. Kaum war sie imstande, die ersten Worte zu sammeln, da gab sie ihrer Umgebung durch Worte und Zeichen zu verstehen, daß sie geheime Gesichte hatte, die sie in einer außergewöhnlichen Gabe des Schauens wahrnahm, ohne daß andere den Anblick teilten.2

1 See Waterman, John T., A History of the German Language, (Prospect Heights: Waveland Press Inc., 1991) 100-101.

2 Gottfried und Theodrich, Das Leben der Heiligen Hildegard, trans. Adelgundis Führkötter (Salzburg: Otto Müller Verlag, 1980) 53, trans. of Vita Sanctae Hildegardis, 1180-1190. 
Thus, the earliest account of Hildegard's life describes her as someone who, already as a young child, received the gift of mystical revelations and was therefore dedicated to God. She was not offered up to the church for this reason alone, however, since during her time it was not uncommon for a family to offer up one of their children as a tithe to the church: "Hildegard was the tenth child of noble parents, who dedicated her to God as a tithe."3

After extensively researching her life, I was led to a different image of Hildegard, one including more than just her mystical prowess. I discovered that she had achieved much more in the "real" world during her lifetime, so much that it overshadowed her role as a mystic. The typical definition of mysticism seems not extensive enough to incorporate all that Hildegard achieved. For instance, according to Evelyn Underhill: It [mysticism] implies the abolition of individuality; of that hard separateness, that 'I, Me, Mine' which makes of man a finite isolated thing. It is essentially a movement of the heart, seeking to transcend the limitations of the individual standpoint and to surrender itself to ultimate Reality; for no personal gain, to satisfy no transcendental curiosity, to obtain no other-worldly joys, but purely from an instinct of love. 4

Hildegard was certainly not lacking in individuality. Her individual spirit poured forth from everything she attempted, from her liturgical

3 Newman, Barbara, Sister of Wisdom: St. Hildegard's Theology of the Feminine (Berkeley: University of California Press, 1987) 5.

4 Underhill, Evelyn, Mysticism (New York: Image Books Doubleday, 1990) 71 . 
music to her many literary achievements. 5 Hers was a "movement of the heart" in that she felt a deep love for God which in turn caused her to reach out to His children (mankind) on earth. She did not, however, seek to "transcend the limitations of the individual" but had faith in the individual, the individual who was for her a physical manifestation of God. She sought to nurture, heal and diminish the limitations of the individual. For Hildegard, life on earth was redeemable and worthy of attention and care. She harbored a dauntless spirit that did not single out eternal life as more worthy of attention than the life an individual led on earth; rather, she was driven to do all that she could to assure that God's will would be expressed in the physical world.

It would seem that Hildegard acted solely in the interest of God and others, but there were moments in her life when her own personal wants, for instance her relationship to the nun Richardis von Stade, took precedence over her selfless duty to God. ${ }^{6}$ If mysiticism implies the total denunciation of personal wants, the "I, Me, Mine," then Hildegard fell short in fulfilling this prerequisite as well. Hildegard's strong emotional tie to Richardis seemed at one point to concern her so much that she began to neglect her selfless duty as God's vessel and servant.

Hildegard believed, as did others before her, that God was manifest in the material and spiritual world, and her quest to unite the two

5 See Weeks, Andrew, German Mysticism from Hildegard of Bingen to Ludwig Wittgenstein (New York: State University of New York Press, 1993) 44-45.

6 See Bingen, Hildegard von, Briefwechsel, trans. Adelgundis Führkötter (Salzburg: Otto Müller Verlag, 1965) 98. 
illustrates her immense curiosity for the transcendental and its connection with the material as well as her familiarity with Platonic cosmology. As Newman states: "She was a Platonist not only by virtue of this or that opinion, but in her most fundamental habits of thought and perception."7 Not the transcendental alone but the joining of the transcendental with the material world concerned her above all else. The "ultimate Reality" was important but to surrender oneself completely to it was neglecting what was of equal importance: the physical world God created on earth.

If, as according to Underhill, mysticism implies the total denunciation of individualism, then Hildegard did not meet the criteria that define the nature of a mystic. If, however, it implies a fervent interest in the salvation of humanity, originating "purely from an instinct of love," then Hildegard thoroughly represented an aspect of mysticism. Hildegard was a social being who did not simply follow the passive life of the eremite; instead, she encouraged active engagement - from others as much as from herself - to denounce the corruption of Church and State, to nurture and care for life on earth. She did not ignore earthly matters to focus only on the eternal life beyond this world; rather she upheld a positive attitude toward the world and felt a special connection with it and therefore a social responsibility to act on its behalf.

Throughout history, according to some philosophical treatises, the idea of women has been connected to the body. Women were seen as linked to this world, a world tainted by the fall in the Garden of Eden. Men, on the other hand, were associated with the spirit and the soul, the

7 Newman 247. 
transcendental: "Put simply, man is associated...with spirit or soul formed directly by God, partaking of his divinity, while woman is assumed to partake of the body, fleshly incarnation being by definition the sign of humanity's fallen condition."8 Women, it seemed, had no connection with the spiritual world and therefore were incapable of comprehending and preaching about it. Hildegard, however alleged a spiritual connection with the world in her claim that she, although a woman, was chosen by God to incarnate His Word on earth as Christ had done years befor. Moreover, Hildegard attached an important significance to Nature and the Virgin, seeing in each an expression of the feminine divine on earth. In accordance with the dogma since Patristic times, Hildegard believed as well that the Church was a feminine expression of God in the world. Ultimately, for Hildegard, it was the feminine expression of the divine that would have a salvational effect on the physical world. Therefore, the term feminine is understood as the idea of the feminine compassionate, nurturing, maternal, gentle and caring - and not the female physical being of a woman. The feminine can manifest itself in all persons, both men and women.

Using Hildegard's letters in German translation, I will show how, in the patriarchal world of the twelfth century, Hildegard - who managed to exceed the typical role of a mystic - emphasized the feminine as salvific as a means to establish a balance in the world, a balance that had been skewed by the corrupt and non-spiritual behavior of Church and State. Where the

8 Bloch, Howard R., Medieval Misogyny and the Invention of Western Romantic Love (Chicago: The University of Chicago Press) 27. 
positive expression of the divine should be, in die Jungfräulichkeit and in Nature - aspects of the feminine divine modelled after the compassionate figure of Jesus Christ - there was instead a negative and non-spiritual, weiblich, attitude reigning in the world. I will preface the thesis with a brief discussion of the era (Ch. 1). In Chapter 2, I will focus first on how Hildegard saw the feminine manifested in the world and how, for various purposes, she expressed it in her letters. In Chapter 3, by citing further examples in her letters, I will concentrate on how she saw a lack of feminine expression in the world and how she viewed the negative result of this lack. Finally, in Chapter 4 I will show how she achieved the expression of this balance. In concluding my paper, I will consider whether she was successful in her efforts: Did she achieve, from others as well as from herself, the balance she sought or were her efforts in vain? 


\section{Chapter 1}

\section{Hildegard's World}

Hildegard was born at the very end of the 11th century, in 1098, in Bermersheim bei Alzey. Some would have us believe that this was a time of little intellectual achievement or few revolutionary ideas in Europe, an era concerned with the difficulty of survival. Hunger, poverty, and the Black Death, not to mention the threat of condemnation by the Church loomed over the heads of many. ${ }^{9}$ Intellectual inquiry was left to those inside the isolated walls of their monasteries and to a few members of the noble classes. Outside those walls was a world veiled in darkness and fear, heightened by the strict doctrines of Christianity that deemed the pursuit of knowledge of the physical world as inappropriate. ${ }^{10}$

Although the western world seemed to have lost the intellectual spirit characteristic of the Roman Empire, the twelfth century introduced a new period of intellectual growth, a renaissance compared to the Renaissance of the 14th to 17 th centuries. Where in the first half of the Middle Ages, scholars were rare and the resources for intellectual pursuit

9 See Manchester, William, A World Lit Only By Fire (Boston: Little, Brown and Company, 1992) 3.

10 See Tarnas, Richard, The Passion of the Western Mind (New York: Crown Publishers, Inc., 1991) 166. 
largely unavailable, it was in the twelfth century when cultural and intellectual activity began to come alive again. The Catholic Church as well began to encourage scholastic pursuit and slackened its earlier exclusion of secular learning.

Into such a world Hildegard was born into and thrived in. On such a world, she succeeded in leaving a lasting impression. With the greatest of odds against her and referring to herself always as "a poor little figure of a woman"11, Hildegard embarked on a mission unlike anyone, man or woman, of her time. As Judy Chicago, a modern feminist, would have it: "Hildegard was one of the greatest and most original thinkers of medieval Europe." 12 Not only was she a visionary but she excelled in many other areas as well: she was a natural scientist, a preacher, physician, poet, song writer, scholar, and active political figure. Her achievements reached far beyond the realm of the visionary, for she concerned herself intensely with matters that troubled and threatened the foundations of the Christian church.

Although Hildegard was born into a patriarchal world in which Aristotelian notions were a deciding factor in the definition of woman as the "imperfect version of the male"13, Hildegard's message was heard by many and she exerted a significant amount of influence upon others. In choosing a monastic lifestyle, a life dedicated to Christianity, Hildegard

11 Newman 3.

12 Chicago, Judy, The Dinner Party ( New York: Anchor Press, 1979) 76. This is a significant quote as it reveals the appeal Hildegard has now for modern women.

13 Bloch 71. 
realized a partial escape from the patriarchy of the medieval world. Within the walls of the monastery, Hildegard avoided the likelihood of marrying at a young age and the certain subjugation to the authority of her husband. But the Church by no means assured complete freedom of expression for women - lay or monastic - in the early twelfth century: "The historical moment that saw the emergence of Hildegard's great visions fell within a period of transition and crisis. The misogyny of the Middle Ages was apparently never more restrictive than in the centuries preceding her ground-breaking public role."14 Yet Hildegard received an outstanding education and was able to develop her own individual spirit within the monastery at St. Disibod. The monastic life brought Hildegard as close as she could come to expressing herself in a male-dominated world. 15

Hildegard entered the monastery at St. Disibod in 1106 at the young age of eight, not uncommon for the times. At this age and earlier, she was said to have experienced visions and exhibited what seemed to be extraordinary behavior. 16 Subsequent visions would follow throughout her lifetime, as well as accurate premonitions of the future, both of which were sometimes so troubling for Hildegard that it would leave her bedridden and ill for days and weeks. ${ }^{17}$

14 Weeks 44.

15 See Bloch, 107 for further discussion of the benefits of a monastic life for women.

16 See Gottfried und Theodrich 53.

17 See Bynum, Caroline Walker, Holy Feast and Holy Fast (Berkeley: University of California Press, 1988) 199-200. Here Bynum discusses the meaning of illness to medieval women and mystics. 
Upon entering the monastery, Hildegard was entrusted to the anchoress, Jutta of Sponheim who, according to the twelfth-century biographers Gottfried and Theodrich, educated her in the Psalter and the Songs of David. These biographers claim that Hildegard, beside her liturgical education, received instruction from no other person. 18 Hildegard was, however, well-read - probably in Augustine and in neoPlatonists of her time - and had also received further education from the monk, Volmar of St. Disibod, her lifelong friend and secretary.

At the age of fourteen, Hildegard took her vows and received the veil from Bishop Otto of Bamberg. The following two decades were significant for her since it was during this time that she expanded her knowledge of the Scriptures, the Church fathers, the monastic liturgy, science, medicine and philosophy. The death of Jutta in 1136 was a profound turning point that left Hildegard as her elected successor. Five years later, she began to compose her first work, Scivias (Wisse die Wege), a compilation of her visions and a major undertaking that would take her ten years to complete.

It is curious that not until the age of forty-two did Hildegard openly recount her revelations:

Im dreiundvierzigsten Jahre meines Lebenslaufes schaute ich ein himmlisches Gesicht... Ich sah einen sehr großen Glanz. Eine himmliche Stimme erscholl daraus. Sie sprach zu mir: 'Gebrechlicher Mensch, Asche von Asche, Moder von Moder, sage und schreibe, was du siehst und hörst!...und schreibe es

18 Gottfried und Theodrich 53. 
nach dem Willen dessen, der alles weiß, alles sieht, alles ordnet in den verborgenen Tiefen seiner geheimen Ratschlüsse'."19

It has been questioned why she waited so long to begin writing down her visions and openly declaring them to others. The only people who knew of her visions were the monk, Volmar, and the anchoress, Jutta. There are speculations that Jutta, upon hearing of Hildegard's visions, thought it better to keep them secret; ${ }^{20}$ she was always ready to remind Hildegard of her duty to remain pious and humble. Perhaps, out of jealously, Jutta purposely downplayed Hildegard's visions so as to withhold any extra attention from her. It is notable that not until after Jutta's death did Hildegard finally proclaim her visions to the world: "...there may be a suggestion that Jutta was in some sense an inhibiting factor to Hildegard's self-expression. It is perhaps significant that the momentous events described only took place after her death." 21

Hildegard's eclectic spirit touched so many areas that one might compare her to the notion of the Renaissance man. Hildegard played a leading role as abbess of St. Disibod and later established her own small monastery at St. Rupertsberg. A prominent medical writer of her time, she wrote books on medicine that portended later speculations on the circulation of the blood and the characteristics of the nervous system. She

19 Bingen, Hildegard von, Wisse die Wege Trans. Maura Bückeler (Salzburg: Otto Müller Verlag, 1981) 89, trans. of Scivias, 1141-1146.

20 See Flanagan 42.

21 Flanagan 42. 
also maintained a variety of remedies for disease that illustrate her vast knowledge of drugs and herbs. Her medical treatments were, for the time in which she lived, quite progressive. As a natural scientist, she cataloged and described plants, particularly those with medicinal properties. A poet and song writer, she composed music. As a philosopher, she developed a theory of the universe that - influenced by neo-Platonism ${ }^{22}$ - stressed the relationship between the divine and mankind (macrocosm and microcosm $)^{23}$ and how the former is manifested in the latter. To place Hildegard in any one specific category does injustice to the vast array of her remarkable accomplishments.

Many of her intellectual, scientific and practical endeavors are written in her extensive correspondence of more than 300 letters 24 . Her letters reveal her active role in Church and social reform, as in her arduous fight against the Katharer: "Denn gar viele sind Mitläufer der Sadduzäer [d.h. der Katharer] in ihrer Lächerlichkeit. Durch diese und andere Sünden der Menschen wird das Gewand der Kirche - die Gerechtigkeit - verzerrt und ihr herrscherlicher Name von Trauer umflort."25 Portraying herself in the image of God's vessel, Hildegard

22 Although it is not mentioned anywhere, it is likely that her theory was indeed influenced by Augustine and neo-Platonism, since it can be assumed she had extensive education in the Greek philosophers.

23 See Weeks 9.

24 The abundant amount of imagery in her letters suggests that her visions played a significant role in them, although I do not have extensive knowledge of her visionary writings.

25 Bingen, Briefwechsel 183. 
exerted an enormous influence on others. She saw herself as the embodiment of God's will, and therefore she felt it her duty to assert herself and admonish the ways of her superiors: "The way Hildegard used the prophetic role in her life paralleled her use of it in her writings. Her conviction that she was privy to God's will gave her the courage to assert herself when she might otherwise have hesitated, and stand up to her superiors when she thought they were wrong." 26 Not only did Hildegard reach out to others with her message, but others looked to her for counsel and advice as well. She was determined that her message would be heard by all.

In her correspondence, for example, Hildegard readily made us of her prophetic calling and occasionally shows courage on matters about which she felt very strongly about. It is in such instances, such as in the following excerpt from a letter she wrote to Pope Anastasius IV, that her position as God's vessel is evident:

O Mensch, das Auge deines Erkennens läßt nach, und du bist müde geworden, die stolzen Prahlereien der Menschen zu zügeln, die deinem Herzen anvertraut sind. Warum wirfst du die Schiffbrüchigen nicht zurück, die sich aus schwerer Gefahr nur durch deine Hilfe erheben können? Und warum schneidest du die Würzel des Bösen nicht $a b$, die die guten, nützlichen, die wohlschmeckenden, süßhaftenden Kräuter erstickt?27

26 Flanagan 190-191.

27 Bingen, Briefwechsel 39. 
Addressing the Pope as Mensch, her stern words are quite astonishing considering to whom she was directing them and the unlikelihood that a twelfth-century woman would maintain correspondence with the Pope at all. Her courage comes from the conviction that he has been neglectful in his duties. Here and elsewhere, Hildegard stubbornly pursued the role as writer, advisor and preacher, roles usually occupied by men in the medieval era. Her purpose in pursuing such roles, however, was to assure the expression of the feminine in the world, to re-establish the balance offset by the corrupt ways of those in power. Her determined personality and genius emerge vividly in her letters, all the while accrediting her knowledge and message to the Living Light. 


\section{Chapter 2}

\section{The Expression of the Feminine in Her Letters}

The masculine terms for God in the Bible have earned the greatest amount of attention over time, although it contains numerous feminine references in relation to God. The Wisdom of God, is always connected with the feminine except perhaps in those languages where there are no gender distinctions:

For in her is the spirit of understanding: holy, one, manifold, subtle, eloquent, active, undefiled, sure, sweet, loving that which is good, quick, which nothing hindereth, beneficent, gentle, kind, steadfast, assured, secure, having all power, overseeing all things, and containing all spirits, intelligible, pure, subtle. For wisdom is more active than all active things, and reacheth everywhere by reason of her purity. For she is the vapor of the power of God, and a certain pure emanation of the glory of the almighty God; and therefore, no defiled thing cometh into her. For she is the brightness of eternal 
light, and the unspotted mirror of God's majesty, and the image of his goodness. ${ }^{28}$

The attributes of Wisdom's femininity - purity, pure, brightness of eternal light, kind, subtle, gentle and vapor of the power of God - heighten the feminine aspect of God. In other passages in the Book of Wisdom, Wisdom is referred to as one who "ordereth all things sweetly" and "teacheth the knowledge of God" and "she teacheth temperance, and prudence, and justice, and fortitude." She is both gentle and powerful in her influence.

It seems significant that Hildegard felt a unique and personal affiliation with Wisdom, a figure she always referred to as Sapientia in her visions, derived from the term saperewhich means to be wise. Hildegard alludes often to Wisdom in her letters as the Living Light, das Lebendige Licht, as the feminine reference to God. Hildegard, through her own "gentle power," parallels aspects of Wisdom herself. She is powerful in that she exerted an immense influence over others, but her influential words were most often of a gentle nature. It was through the gentle but powerful figure of Wisdom, the feminine expression of God, that Hildegard hoped to reach others so as to mend a world filled with corruption.

Hildegard, upon receiving her call from God to write down and publicly proclaim her visions, claimed that the call came from Wisdom,

28 Wisd. 7: 22-26. 
thus accrediting her initial call to the feminine divine aspect of God29. Moreover, Hildegard, whenever she spoke in the name of God, often used the term Living Light.: "Nun spricht wiederum Er zu dir, der das Lebendige Licht ist, das da leuchtet in Höhen und Tiefen und auch im Innersten hörender Herzen sich nicht verbirgt."30 Wisdom, described as "the brightness of eternal light" in the Book of Wisdom, is for Hildegard the manifestation of the Living Light, das Lebendige Licht which exists in all of mankind. Wisdom, as a feminine expression of God, expresses herself in the form of man and woman, God's Word made flesh, and this expression in turn implies a certain maternal quality inherent in mankind, in all things extant on earth as stated in Ecc. 1:10: "And he [God] poured her [Wisdom] out upon all his works, and upon all flesh according to his gift, and hath given her to them that love him." When God's Word became flesh the feminine qualities in God were manifested.

Hildegard expressed a feminine theology ${ }^{31}$ based on maternal qualities, a theology that is readily apparent in her letters: "The major female theologian of the twelfth century, Hildegard of Bingen...develops the idea of God's charity and wisdom as feminine and emphasizes the

29 Dronke, Peter, Women Writers of the Middle Ages: A Critical Study of Texts from Perpetua (203) to Marguerite Porete (1310) (Cambridge: University Press, 1984) 146.

30 Bingen, Briefwechsel 31.

31 See Barbara Newman's Sister of Wisdom for a thorough account of Hildegard's feminine theology. Newman shows Hildegard's feminine perspective of God and her perspective on women in general. 
sacred heart." 32 God is masculine yet He contains maternal aspects as well: loving, caring, nurturing, reaching out, healing, awareness of the needs of His children. She expresses these various maternal aspects of God in a distinct way in her letters: through the use of a metaphorical language founded in the dynamics of nature, and through her perspective on virginity, a revered expression of the feminine divine which in its purity could best express the maternal aspects of God.

For Hildegard, nature signified God's spirit alive in the world. She saw the creative and controlling forces of nature, "Mother Nature" as we often still refer to nature today, as expressions of God's will at work on earth. Hildegard considered the natural and spiritual life as one, the natural an aspect of the divine. She took this concept to another level when she recognized the energy that nourished and enlivened nature as a feminine power; the concept of the natural and spiritual life expanded to include the feminine, the life-giving source of nature. From this perspective it could be concluded that Hildegard envisioned the feminine and spiritual as one. Nature was a powerful influence in the world, an influence Hildegard expresses time and again in her letters.

This feminine power embedded in nature Hildegard termed viriditas, the Latin for viridity, the quality or state of being green: "Viriditas for Hildegard was more than a color, the fresh green that recurs so often in her visions represents the principle of all life, growth and fertility flowing from the life-creating power of God."33 She recognized

32 Bynum, Caroline Walker, Jesus as Mother: Studies in the Spirituality of the High Middle Ages (Berkeley: University of California Press, 1984) 141.

33 Newman 102. 
viriditas as the energy that gives and maintains all life and the symbol for all that is good. Out of the strength of viriditas pours forth an energy that could heal and nurture mankind. In nature, a feminine force of God, Hildegard saw a companion for her social and humanitarian efforts on earth.

In her letters, she refers to the healing forces of nature through such terms as Grünkraft, Gewürzkräuter, Wolken, Blüten, Bäume, Feuchtigkeit, Keimkraft, and Zweigen, and through reference to the four seasons of the year and the four elements formerly viewed, in alchemy, as composing the physical universe: fire, water, earth and air. She applies these terms sometimes to a particular situation and at other times to certain individuals. Through the use of such metaphorical language she was able to assert herself on matters that troubled her and successfully express her message to others. In such a way, she attempted to correct the non-spiritual actions extant in the world, actions neglectful of the feminine divine.

In a letter to Bishop, Eberhard II of Bamberg, Hildegard offers advice on the concept of the trinity: the Father, the Son, and the Holy Spirit. Not only does she reinforce the notion that the three are one but she also emphasizes that underlying this entity is the feminine life-giving force, Grünkraft:"Jedes Ding, in dem keinerlei Kraft ist, ist tot, wie ein von Baum abgeschnittener Zweig dürr ist, weil er keine Grünkraft hat."34 One is like a parched branch that has fallen from its tree when existing without the 
life-giving force, without the feminine side of God, and this she extends to include the notion of the trinity as well. Although God is described in masculine terms, like the Father and the Son, the trinity is not fully complete without the inclusion of the feminine dimension 35 , that part of God manifested on earth in all living things.

In a more personal letter written to Bertha, Queen of Greece, Hildegard uses an abundance of images in referring to God's maternal and nurturing qualities. Hildegard was especially adept at using metaphorical language to magnify the gentleness of God's love and the profound significance of maintaining faith in Him. With a language that is taken from the earth, from nature, Hildegard sought to reinforce the need to care for God's children and the individual's relationship with God, a relationship Hildegard felt He maintained even on a personal level with each individual:

Gottes Geist haucht und spricht: Den Zweig, den Gott liebt, hütet Er im Winter. Im Sommer treibt Er Grün und Blüten aus ihm hervor. Krankhafte Auswüchse, durch die er verdorren kann, nimmt Er ihm. Durch das Bächlein, das im Osten aus dem Felsen quillt, werden andere, schäumende Gewässer weggespült. Denn es läuft rascher. Zudem ist es nutzbringender als die anderen Wasser, da keinerlei Schmutz in ihm ist. Dies trifft auch auf jene Menschen $z u$, denen Gott einen Tag des Glückes und des funkelnden Morgenrotes der

35 See Newman, 64-65. Newman explains Hildegard's use of feminine metaphor to express God's existence in the world. 
Ehre gewährt und die der starke Nordwind mit dem häßlichen Wehen menschlicher Zwietracht nicht niederdrückt.

Blicke also auf zu dem, der dich berührt hat und von deinem Herzen das Brandopfer verlangt, die Gabe [der Erfüllung] Seiner Gebote. Zu ihm seufze auf. Er schenke dir, wie du verlangst aus Not erbittest, die Freude eines Sprößlings. Das lebendige Auge schauft auf dich, es will dich besitzen, und du wirst leben in Ewigkeit. ${ }^{36}$

The beginning of the letter illustrates Hildegard's finesse in the use of imagery. God does not just speak to the queen in the above passage, His Spirit, Geist, gently exhales, haucht, His message to her. Hauchen is often used in reference to the tenderness in nature: der kühle Hauch des Abendwindes. God's message is conveyed to the queen like a cool breeze passing over one's body in the heat of the summer, a refreshing and delicated implication. An erotic insinuation is apparent as well in that hauchen could refer to such close contact with someone that you feel the light sensation of breathing, indicating that someone is close by. The introduction to the letter is so engrossing that it would not fail to capture the attention of its reader, as with all the rich imagery Hildegard employed in her letters.

Often in Hildegard's letters, the maternal concept is applied to God; she refers to Him as the gentle protector His children 37 : "Den Zweig, den

36 Bingen, Briefwechsel 88.

37 See Wisd. 8:1 
Gott liebt, hütet Er im Winter." The Zweig, even the lowliest of God's children is protected by God in the winter. Winter denotes a time of stagnation and darkness, when life is at a standstill, and thus this line implicates that God is there for His children even in times of darkness, when man/woman is at his/her weakest. The next line contrasts the vibrancy of summer to the period when God "treibt Grün und Blüten aus ihm [dem Zweig] hervor." Thus, in the summer, when nature is at her heighth, when the individual is strong and filled with Grünkraft, the complete feminine expression of God's divinity is manifested and poured forth on earth. Anything that might harm or stunt the blooming of the branch, here Hildegard refers to "krankhafte Auswüchse," is removed by God.

In the second half of the first paragraph, Hildegard uses the four elements - water, earth, fire and air - to further describe God's commanding presence in the world and His everlasting concern for the care and salvation of His children. The water element: comes out of the east (where the light rises, the symbol of good) and pours forth a small river of water from the rocks, the earth element, which in turn cleanses the water that has been spoiled, die schäumende Gewässer. Anything that is harmful or no longer nurtures life on earth must be extracted, including the corrupt actions of those who, by their actions, fail to respect the gift of life, "die Ehre des funkelnden Morgenrots." The funkelnde Morgenrot depicts the sunrise on the horizon and the fiery-red image it radiates, a symbol for the fire element and the personification of life at its dawning. Our lives are impassioned with God's love - again alluding to the 
maternal characteristics implied in God's warmth and intensity of feeling for all on earth - a radiating love that cannot be extinguished by der starke Nordwind, the air element and symbol of evil forces in the world.

In concluding her letter, Hildegard reminds Queen Bertha that if she obeys His ways, concentrates on the purity of the spring waters and avoids the discordance brought on by the strong north wind, and fully offers her love up to God, He will nurture her as one of His Sprößlinge. As a small but significant offshoot of God's love, a sprout, she can help ensure the growth and development of faith in God on earth. With the use of nature metaphors, a symbol of the feminine divine in the world, Hildegard explains to the queen that she will ensure the growth of God's faith in the world if she successfully manifests the feminine expression of the divine.

Elizabeth of Schönau, a Benedictine nun and a mystic at the monastery Schönau not far from Bingen, wrote to Hildegard asking her advice about visions she had had. Three of her letters and Hildegard's response are extant. Hildegard replies to the younger mystic with understanding, having had a similar experience of uncertainty about the authenticity and validity of her own visions, and clarifies the reasons for Elizabeth's as well as her own unique role in the world as a Posaune Gottes:

So ändert sich die Welt, o Tochter Elizabeth! Die Welt hat nicht mehr die Triebkraft, aus der das Grün der Tugenden aufsproßt, weder in der Morgenfrühe noch zu ersten, dritten, noch vor allem zur sechsten Tagestunde. In unserer Zeit ist 
es wahrhaftig notwendig, daß Gott bestimmte Menschen betaut, damit Seine Werkzeuge nicht müßig sind.

O Tochter, Gott mache dich zu einem Spiegel des Lebens! Aber auch ich, die ich kleinmütigen Herzens daniederliege und immer wieder von Furcht beunruhigt erlahme, erklinge zuweilen wie ein schwacher Posaunenton des Lebendigen Lichtes. So helfe mir Gott, daß ich ausharre in Seinem Dienst! 38

Because the world no longer maintains the necessary Triebkraft, driving force, out of which spring forth the Tugenden (the Virtues) ${ }^{39}$, the demonstration on earth of God's grace and human cooperation, it is therefore required of individuals like Hildegard and Elizabeth to reenliven this Triebkraft. Hildegard addresses the same issue to the nuns at Zwiefalten: "Doch sehr hart und bitter ist es, wegen der alten Schlange, daß die Triebkraft des Fleisches immer verdorrt bleibt."40 The Triebkrafft of the flesh remains forever barren, verdorrt, in that it does not have the flourishing Triebkraft that underlies the spiritual life. If the nuns remain steadfast in their faith, the Triebkraft will sustain and increase that faith. As virgin brides of Christ, nuns are in the special position to express God's Word, for their purity allows them to be filled with the Holy Spirit that is anxiously waiting to flow from them.

38 Bingen, Briefwechsel 197.

39 See Newman p.16-17. Here she defends the correct translation of the Virtues as Kräfte and not Tugenden.

40 Bingen, Briefwechsel 212. 
Hildegard and Elizabeth and others like themselves are responsible for maintaining das Grün der Tugenden, the positive propelling force, that it may continue to flourish in the world. Again, Grïn denotes here the life-giving energy contained in the concept of viriditas. The fecundity implied in the term Grün, is the flourishing aspect of the Virtues, it is that which enables the growth and development of the Virtues on earth. Thus it is active not passive participation that Hildegard required of Elizabeth and others like her, including herself, to change and improve the existing order of things in the world, an order that she felt was in need of healing.

That God chose two females who were initially filled with selfdoubt 41 , was a controversial notion in the twelfth century. As women in a male-dominated society they had a particular need to authenticate their call, to authorize their visions and their claim to special access to the Word of God. This authentication was crucial to their success as mystics, as vessels of God. In the closing passage of the above letter to Elizabeth, Hildegard underscores the role each must play in the world and assures her that, although their messages may resound like a weak Posaunenton, the effect they can have on the world and mankind is powerful; Hildegard implies that out of weakness comes strength. Thus, the strength of the feminine had found its niche in the vocation of two "poor little"42 females. Hildegard and Elizabeth are those bestimmte Menschen that God has betaut (sprinkled with dew), in other words consecrated, in order that

41 See Bingen, Briefwechsel 25-27. In her first correspondence with the abbot of Clairvaux, she addresses her initial self-doubt about her visionary experienes and looks to the abbot for reassurance and validation.

42 See Newman p.3. 
their purpose on earth, as Posaunen Gottes, achieve effective results and not have been in vain. Finally, in the last lines of the letter, Hildegard refers to God as das Lebendige Licht, here again the reference to Wisdom and the maternal aspect of God.

Hildegard's use of Mother Nature as a symbol of the feminine aspect of God at work in the world sometimes revealed a stormier side of the feminine divine. Nature, with her inherently feminine qualities, was apt to show a more aggressive side as well. We have seen her depicted as gentle, subtle, and delicate in her nurturing and caring for the world. Just as nature gives us winter as well as spring, storms as well as sun, so too does Hildegard's nature at times take a more stringent approach in caring for God's children on earth. When the situation arose in which she recognized corruption, folly or indecision, Hildegard referred to a more relentless, active nature. This more stormy side Hildegard alludes to at times in her letters.

Writing to the prelates of Mainz concerning the controversy over an excommunicate buried at the Rupertsberg cemetery, Hildegard uses the image of black clouds schwarze Wolken to intensify her words ${ }^{43}$. She is seeking to persuade the prelates not to impose an interdict on her convent, an interdict that would be enforced as a result of her refusal to comply with the prelates and remove the excommunicate from her cemetery. Here as elsewhere in her letters, Wolken appear metaphorically to signify ominous events of the past, present or future. Although clouds may sometimes

43 See Newman p.100-107. For a discussion of the meaning behind the term Wolken in Hildegard's visions. 
symbolize protection, shelter or that which shades from the scorching heat, they can also carry a more apocalyptic meaning, eluding to corrupt and sinful actions with the certainty of dire outcomes:

Es handelt sich um einen Toten, dessen Überführung und Begräbnis auf unserem Friedhof durch seinen Priester widerspruchslos stattgefunden hat. Als unsere Obern wenige Tage nach seiner Beisetzung uns befahlen, ihn aus unserm Friedhof zu entfernen, wurde ich darob von einem nicht geringen Schrecken befallen und habe, wie gewohnt, zum wahren Lichte aufgeschaut und mit wachen Augen in meiner Seele folgendes gesehen:

Würde gemäß ihrer Vorschrift der Leib dieses Toten ausgegraben, so würde durch die Entfernung unserm Orte eine große Gefahr drohen und uns umlagern gleich der schwarzen Wolke, die Sturm und Gewitter anzuzeigen pflegt. Deshalb maßen wir uns nicht an, den Leib des Verstorbenen da er ja gebeichtet, die Salbung und Kommunion empfangen hatte und ohne Widerspruch bestattet worden war herauszuholen. ${ }^{44}$

Revealing her more practical side, Hildegard strongmindedly addresses a political matter concerning her convent. She warns the prelates that if she were to comply with their orders, the consequences would be devastating for her and her nuns at the Rupertsberg. She sees the possible outcome appear like a dark cloud, eine schwarze Wolke, that

44 Bingen, Briefwechsel 237. 
forms in the sky before the onset of a thunder storm. Hildegard conveys to the prelates that God, das wahre Licht, proclaimed His warning to her directly. Thus, the use of the term Wolke in the above passage is a foreboding symbol that underscores for Hildegard the grave error in the prelate's decision. Hildegard, confident in her actions and legally in the right, remains steadfast in her decision and defiantly, in the name of the Living Light, refuses to do as the prelates requested of her ${ }^{45}$.

Again Wolken appear as a warning in a letter to the nuns at the Benedictine convent of Woffenheim in Elsaß as Hildegard expresses her concern for the election of a new abbess at the convent and warns them not to offset their decision through unpious behavior. Not the substantive Wolken but the verb umwölken is used here:

Wenn die Sonne in ihrem Strahlen umwölkt wird, liegt Trauer über der Welt, so wie es jetzt bei eurer liebenswerten Mutter der Fall ist. Daher ermahne ich euch im Heiligen Geiste: Bei dem Vorhaben, eine andere Mutter zu wählen, sollt ihr das Laster des Widerspruchs, das Fehlgehen des Stolzes und die Schande der Gottvergessenheit fliegen. Dann wird die wahre Sonne euch ihre Strahle zusenden, so daß ihr diejenigen zur Mutter wählt, die die Stelle Christi in guter Absicht unter euch vertritt. 46

\footnotetext{
45 Later, six months before Hildegard's death, the interdict was finally lifted and she succeeded in retaining the excommunicate at the Rupertsberg cemetery.

46 Bingen, Briefwechsel 206.
} 
Hildegard reminds the nuns of the special significance their decision carries. She emphasizes the ominous state that has befallen the convent by saying the will of God is clouded, umwölkt, and only through the careful and pious judgment of the nuns can the true will of God, die wahre Sonne, be revealed to them. Hildegard is consistant in reminding the newly elected abbess as having the special responsibility of representing Christ's position in the world, acting in his place.

The idea that woman (the feminine) symbolizes the flesh would imply that the incarnation of Christ was a physical manifestation of the feminine divine, the dimension of God that exists in the physical realm. The notion of Christ as feminine was especially popular amongst the twelfth-century Cistercian monks ${ }^{47}$. Attributing feminine or maternal characteristics to Christ, who was the embodiment of God, makes God seem more accessible and loving, ascribes to Him caring and nurturing qualities. Christ was a person who acted in a loving manner, lacking the aggressive and combative characteristics usually attributed to the masculine gender. He proclaimed a message that sought to nurture the children of God and love them no matter what their faults might have been, as a mother would do with her own child.

Since Christ is no longer in the world, God's Word no longer has a physical manifestation in human form; instead, it is left to the clergy and the Church to materialize His Word on earth in an alternative manner: in preaching and spreading faith in God, in a way characteristic of Christ's

47 See Bynum, Caroline Walker, Jesus as Mother: Studies in the Spirituality of the High Middle Ages (Berkeley: University of California Press, 1982) 100-169. 
humanity and love. When Hildegard asked the nuns in the above passage to choose a new abbess of their convent "die die Stelle Christi in guter Absicht unter euch vertritt," she was referring to the abbess's responsibility to materialize God's will in the world, a responsibility that every man or woman of the Church promised to uphold when they took their vows.

With this idea in mind, it is assumed that Hildegard saw the Church and all its representatives, men and women, as perpetuators of the feminine dimension of God. As she says in one of her visions: "Die Kirche ist also die jungfräuliche Mutter aller Christen. Sie empfängt und gebiert ihre Kinder durch die geheime Kraft des Heiligen Geistes und schenkt sie Gott, so daß sie Gotteskinder heißen."48 Thus, when the significance of the nun's roles at the convent in Woffenheim were realized, then the wahre Sonne, God, would pour out her rays to all and with that they will have fulfilled their duty as representatives of God's will on earth.

Most intriguing among the vast array of metaphors Hildegard employs to express the feminine dimension of God was the tree, Baum. Her use of this image initially seems ironic, since a tree would appear to represent masculine rather than feminine characteristics. The sturdiness of its trunk, its powerful branches reaching outward to the sky, the force of its size would all seem to be more appropriately applied to the masculine qualities of God, His strong and judging side.

I propose, however, that Hildegard identified the tree with feminine characteristics, symbolizing God's maternal love and protection of His

48 Bingen, Wisse die Wege 165. 
children on earth. The tree is very much a thing of this world. It represents just as well any other nature metaphor employed by Hildegard to represent the feminine aspect of God, the aspect that manifests Herself in the physical world. Within the image of the tree lie the fundamental characteristics attributed to those who carry the responsibility of caring for God's Church and children. For instance, she depicts the tree as a place of shelter and a source of nourishment for many creatures. It offers protection and shade from the external, sometimes harsh, environment. It is a place where one can find solace, a place of contemplation and meditation, perhaps even a peaceful escape. In Ecclesiastics 24, the arboreal metaphor is used at length to describe Wisdom, the feminine divine: "I was exalted like a cedar in Libanus, and as a cypress tree on mount Sion. I was exalted like a palm tree in Cades... as a fair olive tree in the plains, and as a plane tree by the water in the streets, was I exalted... I have stretched out my branches as the turpentine tree, and my branches are of honor and grace."49 In the Book of Proverbs Wisdom is called the tree of life.

We find a related reference to Baum in the oldest of Hildegard's letters, written to the abbot Bernhard of Clairvaux in 1147, not long after Hildegard received her call from God. She describes the initial uncertainty she felt in her divine position as visionary and the reverence she holds for the abbot. In the following passage of the letter, Hildegard praises Bernhard not only for maintaining his own personal faith in God but for his concern for the faith of others as well: "Nun erhebe ich mich und eile zu dir: Ich sage dir: $d u$ wirst nicht niedergeschlagen, sondern du richtest

49 Ecclus. 24: 17-22. 
ständig den Baum empor und bist Sieger in deiner Seele. Und du richtest nicht allein dich selbst, sondern auch die Welt zum Heile auf."50 The Baum, in that it was exalted by Bernhard, in turn not only nurtured Bernhard's faith but also the faith of God's children on earth. Hildegard thus praised Bernhard for recognizing his social responsibility for matters of this world, a responsibility that, in this letter, she was just beginning to realize was a duty she must fulfill herself as well.

Baum appears in a letter Hildegard wrote to the Konvent at Krauftal. It appears that the spiritual life at Krauftal had been neglected by its nuns. Hildegard uses the arboreal image to remind the nuns of the purpose in their original vows to God:

'Siehe, schon drei Jahre komme ich hierher und suche Frucht an diesem Feigenbaum, finde aber keine', wenn ich die Werke der Liebe, des Gehorsams und der Beharrlichkeit im Guten an ihm prüfe. Er rauscht nur und läßt die lebendige eßbare Frucht nicht zur Reife kommen, da er weder Blüten noch Früchte - Tugenden - noch Blattgrün - heilige Werke noch den vollen Ertrag - die Zucht körperliche Abtötung hervorbringt. 51

Referring to duties of the spiritual life like the fruit, Frucht, of a fig tree, Feigenbaum, Hildegard tells the nuns at Krauftal that she finds no fruit growing there. All the characteristics that make up the healthy fig tree are lacking: works of love, obedience [to God] and perseverance in all that is

50 Bingen, Briefwechsel 26.

51 Bingen, Briefwechsel 209. 
good. The growth that the nuns should yield from their spiritual tree has been stunted and until they correct their ways, the Früchte, Blattgrün and den vollen Ertrag will not materialize at their convent. The spiritual life must flourish, like the fruit of the fig tree, to nourish God's children, a duty assigned to the nuns in their initial vow to God.

Through the use of her various nature metaphors, Hildegard attempted to return the expression of the feminine divine to the world. Whether it be through the Grünkraft inherent in all living creatures or the stormier side of nature, die schwarze Wolken, Hildegard sought to find once again the natural balance in the world which had been tampered with and had resulted in the neglect of the feminine divine.

\section{Die Jungfräulichkeit}

For Hildegard, a further manifestion of the feminine divine on earth was indie Jungfräulichkeit, the most highly revered position for a woman. In several letters, Hildegard addresses this topic and defends the divine status of virginity in the world. For Hildegard, as for the majority of her peers, the Virgin Mary represented the most highly revered figure in the medieval Church:

In Catholicism, Mary is the archetype for virginity and all that is pure in the world. For Hildegard, Mary also symbolized the reconciliation for Eve's sin in the Garden of Eden. Mary regained that which was envisioned by God before time and before Eve's fateful fall: pureness coupled with maternal love: "Through the virgin birth Mary conquered 
the post-Eden natural law that man and woman couple in lust to produce children. Chaste, she escaped the debt of Adam and Eve."52 Mary's divine love gave birth to God's Word in the flesh, in the form of Christ, the Son of God. She, like Christ, was a part of God's plan, to give birth to His Word on earth, a plan that had gone awry because the first woman, Eve:

O Stein, du sprühest vom Licht, vom klaren Glanz der Sonne,

Die dich durchflutet,

Der Sonne, die dem Herzen des Vaters entquillt.

Sie ist des Vater eingeborenes Wort,

Durch das Er schuf der Welten Urgestalt,

Die Eva verdunkelt hat.

Dies Wort hat, Vater aus Dir den Menschen gebildet.

Darum bist du, o Jungfrau, das leuchtende Sein,

Daraus das Wort, das göttliche,

Die Gotteskräfte hauchte,

Wie Es jedes Geschöpf in seiner Urgestalt

Ins Dasein rief. 53

In the above lyrical passage from her work, Scivias, Hildegard envisions Mary as the shining jewel, Stein, that bore Christ, the sunlight, that dissipated the darkness brought on by Eve, thus pouring out God's

52 Warner, Marina, Alone of All Her Sex (New York: Vintage Books, 1983) 52.

53 Bingen, Wisse die Wege 351. 
Word on earth like a fountain springing from the Father's heart. Through Mary, God recreated His original notion of the divine presence in the world by filling her with the Holy Spirit which in turn became physically manifested in the form of God's son, Jesus Christ. Mary's splendor allowed for a second chance for mankind, a chance born out of a woman. As both virgin and mother she represents the ultimate perfection for women, an unattainable standard for any other woman. Hildegard adored Mary not so much in her physical form as a person but as an ideal, an ideal that best represented God's presence in the world. Therefore for Hildegard, the status of virginity, accompanied by the nurturing, motherly side of the feminine, was the closest a woman could come to meeting this ideal.

Hildegard makes particular reference to virginity, die Jungfräulichkeit, in her letters, eluding to and defending its divinity and sacred purpose in the world. The purity and holiness of virginity empowered the virgin to prevail against the impurities extant in the world: "Thus the invincible association of holiness with physical virginity, of the power of chastity over evil, dyed the entire fabric of the Marian cult from its official beginnings in Byzantium".54 In a letter to the nuns at Zwiefalten, for instance, Hildegard encourages them to remain steadfast in their marriage to God by extolling the virtuousness of their sacred matrimony as opposed to the sinfulness implied in a marriage with "einem irdischen Mann." In their marriage to God, the nuns are best able to serve Him and carry out their social responsibility of spreading His

54 Warner 67. 
Word on earth, a social responsibility that, according to Hildegard, is their duty in representing the ideal attached to the status of a virgin.

Wenn eine Frau die eheliche Bindung an einen Gatten verschmäht, weil sie - Gottes wegen - sich einem Mann nicht vermählen will: welch großer Adel ist das in ihr! Die bräutliche Verbindung mit dem höchsten König steht ihr zu, weil sie einem irdischen Mann entsagt hat. Sie muß bleiben, wie Eva war, bevor Gott diese dem Adam zuführte. Nicht auf Adam schaute sie, sondern auf Gott. ${ }^{55}$

Hildegard did not believe the monastic life was appropriate for all women; however she admits that those women who choose marriage with a man have the special duty to obey him with humility, like the nuns obey God and remain humble in serving Him. But the status of virginity was higher in rank for Hildegard. By turning away from the pleasures of the body to unite spiritually with God, women could save themselves from the corruption of sexuality, a base act, according to Hildegard, brought by the Devil to corrupt the divinity God had originally intended to manifest in mankind through the creation of Adam and Eve. ${ }^{56}$

Hildegard praises the women who choose to unite "mit dem höchsten König" and exalted such a sacred choice as noble, "welch großer Adel ist das in ihr!." She states that chaste women, here Hildegard is

55 Bingen, Briefwechsel 212.

56 See Newman p121-155. In this chapter entitled "The Daughters of Eve", Newman elaborates on Hildegard's attitude toward sexuality, for both man and woman, and the unusual amount of knowledge Hildegard, as a virgin, had on the subject of sexuality: "For all her warnings against the flesh, she was neither naive nor prudish", p. 131. 
indirectly referring to the nuns, must remain like Eve, before she was brought to Adam by God. Here it seems that Hildegard places partial blame on God because He was the one who originally brought Eve to Adam. Before that, Eve had looked only to God, "nicht auf Adam schaute sie, sondern auf Gott." Her letter, thus, becomes a plea to the nuns to arm themselves against the evils of the flesh, so that they can remain devoted to God.

The concept of virginity was taken perhaps to an extreme by Hildegard, when considering a custom practiced at her convent. The custom had to do with the magnificent liturgy at the Rupertsberg in which Hildegard and her nuns dressed themselves in extravagant gowns, wore crowns upon their heads and adorned their fingers with golden rings. The ceremony received strong criticism from the abbess Tengswich of Andernach, a ministerial's daughter and the abbess of an Augustinian convent. In a letter to Hildegard, the abbess reproaches Hildegard for what she considers a religious ritual outlandish beyond measure, criticizing above all else the dress code of the nuns:

Auch von einem sonst nicht üblichen Brauch bei Euch drang etwas an unser Ohr: daß nämlich Eure Nonnen an Festtagen beim Psalmengesang mit herabwallendem Haar im Chore stehen und als Schmuck leuchtend weiße Seidenschleier tragen, deren Saum den Boden berührt. Auf dem Haupt haben sie goldgewirkte Kränze, in die auf beiden Seiten und hinten Kreuze und über der Stirne ein Bild des Lammes harmonisch eingeflochten sind. Auch sollen die Finger der 
Schwestern mit goldenen Ringen geschmückt sein. Dies alles, obgleich der erste Hirt der Kirche solches verbietet, da er mahnt und sagt: 'Die Frauen sollen sich sittsam halten, nicht mit Haargeflecht und Gold und Perlen oder mit kostbaren Gewand' [sich schmücken]. 57

This does seem to describe rather immodest behavior: free flowing hair, white gowns, golden rings on their fingers and crowns upon their heads. How could it be that these women, who have chosen a life of humility and piousness, would be allowed to flaunt their (earthly) femininity by dressing themselves in lavish clothing, "mit kostbaren Gewand," and adorning their fingers with gold rings, "mit goldenen Ringen"? According to the Scriptures quoted by the abbess (1 Tim. 2:9-10), women should not adorn themselves in precious clothing, rather they should remain sittsam, modest and virtuous. Hildegard responds in her own defense:

Höre! Die Erde läßt das gründende Gras sprossen, bis der Winter über sie kommt und ihr die Schönheit des Blühens nimmt. Diese kann sich fürder nicht mehr so offenbaren, als wenn sie niemals verwelkt wäre. Denn der Winter hat sie hinweggerafft. Daher soll auch das Weib sich mit seinen Haaren nicht großtun, sich nicht schmücken noch hervortun durch irgendwelche Kostbarkeit von Krone und Goldschmuck, außer nach dem Willen ihres Mannes, damit sie ihm gefällt, wie es sich gebührt. Das alles gilt nicht für die

57 Bingen, Briefwechsel 201. 
Jungfrau. Diese steht vielmehr in Einfalt und Unversehrtheit wie im schönen Paradies, das nie verdorrt dastehen wird, sondern immer der vollen grünenden Kraft ihrer Blüte, die dem Reis [Christus] entsprang. Für die Jungfrau besteht nicht die Vorschrift, die Schönheit ihres Haares zu bedecken, sondern aus eigenem freien Willen verhüllt sie in tiefster Demut ihr Haupt. Denn der Mensch soll seine Seelenschönheit verbergen, damit der Habicht des Hochmutes sie nicht raubt. Die Jungfrauen sind im Heiligen Geist der Heiligkeit vermählt und der Morgenröte der Jungfräulichkeit. Deshalb steht es der Jungfrau zu, ein leuchtend weißes Gewand anzulegen - kraft der Ermächtigung und Offenbarung durch den geheimnisvollen Anhauch dessen, der der 'Finger Gottes' heißt. Es ist die klare Hindeutung auf ihre Vermählung mit Christus. ${ }^{58}$

At first it appears that everything but a solid explanation is given. Hildegard sidetracks the issue by elaborating at length the virtuousness of virginity and how the virgin dwells outside the realm of the average woman. The abbess' rules apply to married women only. Hildegard alleges that women who are married must cover their hair, maintain modest behavior, and submit to the wishes of their husbands. This, she then adds, does not apply to the virgin. The virgin, in her pureness, stands outside the evils of the world, and has therefore the right to adorn herself

58 Bingen, Briefwechsel 202. 
in white gowns in celebration of her marriage to God 59 . Only in humility she chooses to veil her head. She celebrates her virginity, untouched by the sin of Eve.

At first, in the above passage, it seems as if Hildegard becomes too involved in extolling the virtues of the virgin, avoiding a concrete answer to the abbess' concerns about the customs at the Rupertsberg. Hildegard's defense of the magnificent liturgical ceremonies at her convent coincides with her theology of the feminine. For Hildegard, the ceremony celebrates the original idea of woman, as God envisioned her before the fall of Eve, a celebration of the eternal Feminine, the feminine dimension of God. She saw the ceremony as a grand celebration of God's divine presence on earth as manifested through her and these brides of Christ, a celebration no married woman is capable of performing. The reasons for the extravagant ceremony at her convent seemed self-evident to Hildegard; whether her reasoning convinced the abbess Tengswich or not is unknown. 60 Furthermore, whether the accusations of the abbess were true are not entirely known; however it is evident from Hildegard's response that she did not deny the accusations made by the abbess about she and her nuns participating in lavish ceremonies. Also, that the nuns chose of their own accord, aus eigenem freien Willen, to veil themselves does not necessarily mean that they most definitely did so.

59 See Newman, p.222. Here Newman mentions the fact that the notion of the nuns at the Rupertsberg wearing crowns and adorning themselves with rings was possibly derived from Hildegard's visions. She cites proof of this from Hildegard's Scivias II.5.

60 There exists no proof of a second letter written by the abbess Tengswich in reply to Hildegard's reasons for her customs at the Rupertsberg. 
In one of her most eloquent letters, written in the form of a eulogy, Hildegard illustrates the unique purpose of die Jungfrau in the world as embodied in one specific woman. The letter is addressed to Archbishop Hartwig of Bremen and concerns the death of his sister, Richardis of Stade, a woman with whom Hildegard had a very close relationship and whom she loved dearly ${ }^{61}$. In the letter, Hildegard praises Richardis for her devotion to God and above all the divinity of her virginity 62 . Hildegard states that she was called by the Living Light to love her and that, in Richardis, Hildegard saw God's Word come alive:

Oh, wie groß ist das Wunder bei der Rettung jener Seelen, auf die Gott so geschaut hat, daß Sein Ruhm in ihnen nicht verdunkelt wird! Doch Gott wirkt in ihnen wie ein starker Streiter, der danach eifert, daß er von niemand überwunden werde und Sein Sieg Bestand habe. Nun höre, o Teurer: also geschah es mit meiner Tochter Richardis, die ich meine Tochter und zugleich meine Mutter nenne. Denn mein Herz war voll von Liebe zu ihr, weil das Lebendige Licht in einer starken Schau mich lehrte, sie zu lieben.

Höre: Gott hatte mit solchem Eifer von ihrer Seele Besitz ergriffen, daß die Lust der Welt sie nicht zu umgarnen vermochte; sie kämpfte vielmehr ständig dagegen, obgleich sie wie eine Blume erschien in der Schönheit und Zier und

61 See Bingen, Briefwechsel, p.98. For a closer look at the love Hildegard felt for Richardis in a letter addressed to Richardis herself.

62 See Newman, p. 222. Newman considers the possibility that Hildegard envisioned Richardis as "Virginitas herself". 
Symphonie dieser Welt. Doch als sie noch im Leibe weilte, hörte ich in einer wahren Schau von ihr sagen: 'O Jungfräulichkeit, du stehst im königlichen Brautgemach!' Denn im jungfräulichen Reis ist sie eingereiht in die hochheilige Ständeordnung. Darüber freuen sich die Töchter Sions. Und doch wollte die alte Schlange sie durch den hohen Adel ihres menschlichen Geschlechtes von dieser Ehre abziehen. Da aber zog der höchste König diese meine Tochter an sich und schnitt allen menschlichen Ruhm von ihr ab. Darum hegt meine Seele großes Vertrauen zu ihr, obgleich die Welt ihre Schönheit und Klugheit liebte, als sie noch in der Welt lebte. Doch Gott liebte sie noch mehr. Darum wollte Er Seine Geliebte dem feindlichen Liebhaber, der Welt, nicht überlassen. ${ }^{63}$

Richardis was both a daughter and a mother to Hildegard, a daughter in the sense that Hildegard, her elder, felt a spiritual affiliation to her as a person, and a mother in the sense that Hildegard looked up to and revered Richardis as the embodiment of God's presence in the world. She was, as told to Hildegard in a vision, the epitome of virginity: "O Jungfräulichkeit, du stehst im königlichen Brautgemach." She was like a Blume, a flower, that dwelled in the beauty of this world, the world as God's bride, im königlichen Brautgemach. The beauty, die Schönheit und Zier, is found wherever God is present in the world. Nevertheless, filled with God's Eifer by virtue of her virginity, she fought whole-heartedly

63 Bingen, Briefwechsel 100. 
against the evils of this world, die Lust der Welt - more specifically sins of the flesh. Perhaps, however, Richardis was too perfect for a world that was tainted with imperfection, die feindlichen Liebhaber, and was too precious to have to concern herself with the toils inflicting the world. Thus, God, whose love for her is stronger then the menschliche Liebe took her from the world, "da aber zog der höchste König [God] diese meine Tochter an sich."

In the closing of her letter, Hildegard implores Hartwig to fulfill the will of his sister's soul by continuing the good works she carried out while on earth. In this way, he, in turn, would fulfill Christ's position on earth: "Nun erfülle, o teurer Hartwig, der du Christi Stelle einnimmst, den Willen der Seele deiner Schwester, wie es die Notwendigkeit des Gehorsams erheischt. Und wie sie allzeit für dich besorgt war, sei du es jetzt für ihre Seele und verrichte gute Werke, wie sie es erstrebte."64 With these words, Hildegard apotheosizes Richardis' special role: as messenger of God's will, she was the epitome of virginity and the expression of the feminine divine in the flesh.

Through the depiction of Hildegard's reverence for Richardis and what she represented - purity and all that is good in the world - Hildegard's perspective on the feminine divine and how it is expressed in the world was revealed. Above all, Hildegard felt the virgin the most capable and perfect manifestation of the feminine expression of God, an expression that could have a salvational effect on the physical world that seemed to be falling further away from the spiritual.

64 Bingen, Briefwechsel 100. 


\section{Die weibische Zeit}

Hildegard's mention of the negative aspects of the feminine as "die weibische Zeit," effeminate times, seems a contradiction to her feminine theology. During the time in which Hildegard lived, there was a high level of corruption in the Church as well as in the secular realms of power. Church and state leaders and the clergy had lost their strength of purpose, according to Hildegard, a strength founded on a maternal love that cares for and nurtures the people and things of this world. Oddly enough, she termed this period as "die weibische Zeit," in Latin terms, muliebre tempus.:

In her vehement denunciations of the effeminate age, Hildegard condemned a Church whose vain, pleasure-loving prelates had lost all fortitude and zeal for the Word of God in their craving for worldly honor, soft living, and wealth... Where they ought to be bold and manly, they display nothing but feminine softness; where they should be maternal and tender, they reveal only hardness of heart; where they should imitate the virginity of Christ and the Church, they pollute themselves in fornication. In short, they possess the virtues of neither sex and the vices of both. 65

The derogatory connotation implied in terming the times effeminate was not a contradiction to Hildegard's theology of the feminine; 
on the contrary, it seemed to enhance it. As Newman states in the above passage, Hildegard was telling them 66 that "they possess the virtues of neither sex and the vices of both." The virtues of the feminine I have stated at length in the last chapter. For Hildegard, it was simply the most efficient way to seize the attention of those she was addressing, to awaken them from their stupor that had rendered them weak, weibisch, and had impeded their ability to act in the name of God. It was to scold and chastise those who worked in the name of God, those who had forgotten the maternal elements in their sacred role as God's servants: to love and nurture the earth. By describing the times in such a manner, she was certain to receive an immediate, if not astonished, reaction from those whom she addressed. In a patriarchal world, one could imagine that neither pope, king nor layperson would want to believe they were fostering conditions that could be labeled weibisch.

Referring to the effeminate times, die weibische Zeit, in a letter to King Konrad III, Hildegard tells him that he has turned away from God and that the times he lives in "sind leichtfertig wie ein Weib." Although he is considered by rank a powerful figure in the world, his laxity in defending God's Church has rendered his efforts weak and ineffective, weibisch:

Höre: In gewisser Weise wendest du dich ab von Gott. Die Zeiten, in denen du lebst, sind leichtfertig wie ein Weib. Sie

66 Here them refers not only to the Church hierarchy but the heads of state as well. As is clear from her letters, Hildegard was addressing her words of reproach just as much to those in charge of state affairs as those serving God's Church. 
neigen sich auch einer feindseligen Ungerechtigkeit $\mathrm{zu}$, die danach strebt, die Gerechtigkeit im Weinberg des Herrn zu vernichten... Der Weinberg des Herrn raucht von Leid. ${ }^{67}$

Die Gerechtigkeit in God's vineyard - the vineyard representing here God's earth and its creatures - is threatened by the hostile forces of die Ungerechtigkeit, all that which hinders the expression of God's will on earth. God's kingdom on earth reeks of pain and this is a result of those who have been left in charge of its care. They, like Konrad, have become fickle, weibisch, straying from God and failing in their duty to care for and nurture God's Church and children. They have become forgetful of their duties that carry a positive expression of the feminine on earth, the maternal strength necessary to effectively exercise the power entrusted to them by God.

In this chapter, we have seen how Hildegard saw the feminine dimension of God expressed in the world through the sacred status of die Jungfräulichkeit, and the metaphorical language she employed to reveal the expression of the feminine, based especially on various elements in nature. We also saw how she believed the Church played a major role in expressing the feminine aspect of God on earth. However if they neglected their duties, a negative aspect of the feminine manifest itself, an aspect Hildegard termed weibisch, By referring to the times asweibisch, frivolous, Hildegard was showing their neglect of the positive feminine divine in the world. The Word, once born into the figure Jesus Christ, must now be born anew by those with the responsibility of perpetuating His will on

67 Bingen, Briefwechsel 80-81. 
earth: the Church leaders, the clergy and even the heads of state. As God is feminine in His presence on earth, everything that supports this presence represents the feminine dimension of the divine. 


\section{Chapter 3}

\section{The Lack of the Feminine Divine}

To lament the lack of the feminine in the world, Hildegard addresses the issue in her letters to various persons: popes, emperors, bishops, monks and fellow nuns. As with her discussion of the feminine in the world, she turned to the natural world for images of worldly corruption. Such metaphorical terms as Dürre and Finsternis and references to animals, Hunde, Bären, Hühner, appear often in her letters and will be touched on briefly below. In this chapter, I will specifically consider those letters she addressed to Church leaders, heads of state and various members of the clergy, letters she wrote with hopes of awakening them from their desperate actions.

Hildegard firmly maintained that she was weak, "Ich, erbärmlich und mehr als erbärmlich in meinem Sein als Frau"68, but that God had chosen her to proclaim His will because those who had originally been given the authority to do so - the male Church hierarchy - had failed. As in 1 Corinthians, 1:25-27: "For the foolishness of God is wiser than men, and the weakness of God is stronger than men...the foolish things of the world has God chosen to put to shame the 'wise', and the weak things of

68 Bingen, Briefwechsel 25. In a letter she wrote to the abbot Bernhard von Clairvaux. 
the world has God chosen to put to shame the strong," so was Hildegard chosen by God to instruct the strong and 'wise' of the Church. Therefore, it is not surprising to find many of her more than 300 letters addressed to powerful and influential figures. Hildegard felt that their concern for nurturing God's earth had dissipated and that she, as God's vessel, must step in to repair the disorder.

In a letter to Pope Anastasius IV, Hildegard comes to the defense of the heavenly bride and God's Church on earth, die Königstochter Gerechtigkeit. She had been left, after the death of Christ, to the care of God's servants, but had been neglected even by the Pope, who failed to act on her behalf. The divine daughter of righteousness, die Konigstochter Gerechtigkeit, is God's presence in the world. This feminine aspect of God is presented in the following passage as the savior and protector of God's people, a savior who, like Christ, suffered severe neglect and persecution. Hildegard, as messenger of the Living Light, is compelled to express her discontent for the Pope's incapacity in dealing with the people entrusted to him by God.

Die Königstochter Gerechtigkeit, die himmlische Braut, die dir anvertraut ward, vernachlässigst du. Denn du duldest, daß diese Königstochter zu Boden geworfen wird. Ihr Diadem und der Schmuck ihres Gewandes werden zerrissen durch die Sittenroheit der Menschen, die wie Hunde bellen und wie Hühner, welche manchmal in der Nacht zu gackern anfangen, alberne Töne von sich geben. Heuchler sind sie, die mit ihren Worten einen trügerischen Frieden zur Schau 
tragen, innerlich aber im Herzen mit den Zähnen knirschen, wie der Hund, der die ihm bekannten Freunde mit dem Schwanz anwedelt, den erprobten Krieger hingegen, der sich für das Königshaus einsetzt, mit den Zähnen beißt. Warum duldest du die schlechte Lebensführung der Menschen, die in der Finsternis der Torheit sind, alles Schädliche an sich ziehen, so wie die Henne die nachts schreit, sich selbst Schrecken einjagt? Die so handeln, wurzeln nicht im Guten. 69

Hildegard's reference to the Schmuck ihres Gewandes signifies a deity in its feminine form. The custom of dressing in white gowns and adorning heads with crowns at the Rupertsberg comes to mind here. Moreover, the Diadem in the same line is a reference to the feminine aspect of God. This term appears in one of Hildegard's visions in which she sees an image of a woman, Ecclesia, a figure who represented the divine and epitomized the whole Church.70 The medieval Church was gloriously outfitted as befits the richest queen and the figure Ecclesia is generally depicted wearing a crown. In her first vision of Ecclesia, the description of her matches the in the above letter to Pope Anastasius: "Danach sah ich ein Weib von so hoher Gestalt, das es wie eine große Stadt anzuschauen war. Sein Haupt war mit wunderbarer Zier gekrönt. Von seinen Armen ging, herabfallenden Ärmeln gleich, ein heller Glanz aus,

69 Bingen, Briefwechsel 39.

70 See Newman, p.196. Newman describes in detail "the exalted feminine figure named Ecclesia: bride of Christ, inviolate virgin, mother of the faithful" in her chapter entitled "The Bride of Christ". 
der vom Himmel bis zur Erde niederstrahlte. ${ }^{71}$ Hildegard's theology of the feminine surfaces in the letter to the pope as she professes her salvational purpose in the world, a purpose entrusted to those who represent Mother Church.

The responsibility for the Church consigned to the Pope, however, had been disregarded by him. According to Hildegard, instead of correcting the errors of the people, he was allowing them to continue along their path of corruption. Hildegard was appalled by his lackadaisical behavior, "warum duldest du die schlechte Lebensführung der Menschen, die in der Finsternis der Torheit sind...?" Hildegard describes the people as hypocrites and dogs, Hunde, who are biting at the heals of the Pope who defends God's Church, das Könighaus. They are dwelling in the darkness of their own foolishness and are in need of the guidance and loving care available to them from those, like the Pope, who have been wrapped in the Gewand der Königstochter, enshrouded in the spirit of God. She calls upon the Pope to wake from his idleness in this time of unruliness and protect Mother Church from the Sittenroheit der Menschen.

Not the Church leaders alone had been neglecting their duties to care for the world but the state leaders - kings, emperors, dukes - as well. Authorized by her status as God's vessel, Hildegard audaciously reprimanded leaders of state for allowing unrighteous behavior to flourish in the world. In a letter to Duke Welf VI, for example, Hildegard accuses him of immoral behavior and asks that he correct his ways: "Warum also sagst du dich los von der Einladung Gottes durch einen unbeständigen

71 Bingen, Wisse die Wege 161. 
Lebenswandel, Großsprecherei und den Rausch der Sündenlust? Zudem befindest du dich in tiefer Finsternis wegen deiner unrechtmäßigen Verbindung. Gott will die Einehe, so wie Leib und Seele eins sind... Gott erwecke dich, so daß du aufwachst aus dem Rausch deiner Sünde".72 Hildegard, completely aware of the duke's waywardly behavior, Rausch der Sïndenlust, urges him to mend his ways for the sake of redeeming himself in the eyes of God. Due to his unlawful relations, Unrechtmäßige Verbindung, he dwells in the depths of darkness, in tiefer Finsternis, and therefore has separated himself from God, the Living Light.

Hildegard's reproachful words address a time neglectful of the feminine divine in a letter addressed to another prominent leader, emperor Friedrich I, otherwise known as Barbarossa. In the first of four existing letters to the emperor ${ }^{73}$, Hildegard reminds him of his duty to Gerechtigkeit in a time of corruption and unruliness:

Nun, o König, schau sorgsam zu! Alle Länder sind umdunkelt von den Ränken der vielen, die durch die Schwärze ihre Sünden die Gerechtigkeit auslöschen. Räuber und Abirrende zerstören den Weg des Herrn. O du König, bezwinge mit dem Zepter der Barmherzigkeit die trägen, unsteten und wilden Sitten. ${ }^{74}$

72 Bingen, Briefwechsel, 87.

73 With each letter to the emperor, Hildegard's reproaches become more severe until, in the last of the four letters, she must resort to catastrophic threats, an issue I will consider in more detail in the last part of my paper.

74 Bingen, Briefwechsel 82. 
Not with aggression or rage does Hildegard call upon Friedrich to combat the evil ways of the Räuber and Abirrende who are attempting to destroy Gerechtigkeit, rather with compassion and mercy: die Barmherzigkeit. It was this quality - one more often associated with a mother than a father, the quality embraced by Christ and often attributed to the Virgin Mary - that Hildegard espoused when calling upon Friedrich to defend den Weg des Herrn. With that which appears weak, compassion and mercy, one can overcome severe and unruly conditions, "die trägen, unsteten und wilden Sitten." Thus, according to Hildegard, to overcome the effeminate times, the positive feminine quality inherent in the passivity of compassion can be just as effective as fighting with the sword.

There are, in addition to those letters written to Church leaders and heads of state, many letters from Hildegard addressed to the clergy: abbots, priests and monks. She wrote to them, too, of Church reform and mending the corruption afflicting God's earth. Again, as in her letter to the Pope and the emperor, she asked that they work with compassion, applying the maternal aspects of God - die Barmherzigkeit and love - in influencing others, rather than with fury or aggression, as in the Scriptures: "But go, and learn what this means: I desire mercy, and not sacrifice. For I have come to call sinners, not the just."75 In the following excerpt from a letter written by Hildegard to an $\operatorname{abbot}^{76}$, she refers to such

75 Matthew 9:13.

76 Unfortunately, some of the extant letters written by Hildegard do not reveal the names of the addressee, as in this letter written to an anonymous abbot. 
Biblical passages that support compassionate behavior in guiding the people away from their sinful ways:

Ich hörte aber in der Schau meiner Seele folgende Worte: Hüte dich, o Mensch, höher emporzusteigen, als deine Kraft $z u$ tragen vermag. In all deinen Unternehmungen umfange vielmehr die süßeste Mutter der Gotteskräfte, die Maßhaltung, damit du von ihr durch alles hindurchgeführt wirst und nicht etwa zu Fall kommst. Denn der Hirte, der den Stab der Zucht ohne Diskretion handhabt, ist Gott nicht wohlgefällig und wird auch von seinen Schafen nicht geliebt, sondern wird ihnen eher Anlaß zum Haß. Guter Vater, leit deine Herde mit Barmherzigkeit! So ahmst du Gott nach, der die Barmherzigkeit lieber will als das Brandopfer. Bemühe dich auch, all deine Werke in jener wahren Demut zu tun, durch die die wahre Sonne, Gottes Sohn, von der Burg des Vaters in den Schoß der Jungfrau herabstieg, auf daß du in Ewigkeit mit Ihm lebest!77

First, Hildegard reminds the abbot not to exceed the limits of power assigned to man but to remain true to the sweetest mother of divine powers: die Maßhaltung, moderation. The balance and harmony in such moderation indicates a gentle if not passive approach to existing matters or conflicts, as opposed to the rash behavior of acting solely on one's natural aggression in combating opposing forces. Again, Hildegard refers here to the maternal characteristics of God, His feminine expression, in dealing

77 Bingen, Briefwechsel 179. 
with His Schafen, children, on earth. By acting with discretion, the abbot can avoid coming to grief, zum Fall kommen, and avoid the hatred of the people as well.

Finally, Hildegard calls upon the abbot to act in a way that best imitates God, a way that is founded on Barmherzigkeit. In this way, the abbot can recall and honor the purpose of Christ who was conceived by the Virgin Mary and made flesh on earth. In acting with compassion and Demut, humility, the abbot can reinforce the Word of God as it was once manifested in the compassionate and loving figure of Christ, whose purpose it was to act with mercy in guiding God's people back to Him.

There was an obvious neglect of the feminine divine in the world, a neglect that was reflected in the actions of those entrusted with the care of God's earth and children. To ensure the correction of their corrupt ways, Hildegard addressed Church leaders, members of the clergy, monks and nuns as well as heads of State in her letters. She felt it her duty as God's vessel to remind them of their responsibility to nurture the world, a world that was a reflection of the feminine divine. 


\section{Chapter 4}

\section{How Hildegard Achieved \\ a Balance Herself}

Hildegard sought to achieve a balance between the feminine and the masculine expression of God in the world. Although she maintained a feminine theology, this did not deny that she believed there also existed masculine qualities in God that were necessary as well in executing His will on earth, such qualities as boldness, forcefulness and fortitude. The two sides appear contradictory, but for Hildegard they were both necessary in securing a healthy balance in the world. Mostly, Hildegard envisioned a compassionate God; however, at times the only apparent means available to broadcast her message to others was a more forceful side of God, a side that at times bordered on the apocalyptic: "And, like the great seers of the Old Testament, she sought by all possible means to bring the people of God to repentance. To that end she used both threats of catastrophe and promises of grace, conveyed in graphic and often startling imagery."78 As discussed in Chapter II, Hildegard used symbols from the world of nature and referred to the divinity of Jungfräulichkeit in representing her feminine theology. Her eloquent use of metaphorical language in depicting the feminine dimension of God and her reverence for her status

78 Newman 27. 
as a virgin both exemplify a side of Hildegard that was inherently feminine in its expression. Her feminine side, however, found its ultimate manifestation in her devotion to the social responsibility required of her sacred position in the world: "Her positive sense of the religious capacities and role of women is based in a sense of female otherness from male authority. Her 'feminine' images for divine aspects refer either to the Spirit, which inspires us, or to the creative work of the entire Trinity."79 Acknowledging the feminine divine was not enough for Hildegard; most important to her was the action that perpetrated the feminine dimension of God. Thus, retreating to lead the passive life of a hermit ${ }^{80}$ did not fulfill the social responsibility these individuals had in caring for God's earth and children. Hildegard was extremely engaged in her world, a world she saw as based on God Himself. Although it was usually the duty of the superior (abbess or abbot), she felt it the duty of others as well to assist her in nurturing and inspiring others in the ways of God. 81

In a letter seeking advice, the abbess, Sophia of Altwick, expresses to Hildegard her wish to lay down the burden of pastoral care, which has weighed heavily upon her, in exchange for an eremitic life: ."..ich soll die

79 Bynum, Jesus as Mother 142.

80 Nowhere did I find it stated by Hildegard that social responsibility was a specific duty for women alone and that men could retreat into an eremitic lifestyle. I think she felt it was everyone's duty - those persons who served God's Church as well as His world, state leaders - to care for God's children and His earth. Of course it must be acknowledged that hermits were holy as well and had a specific role to play in the spiritual life.

81 See White, Donald A., Medieval History: A Source Book (Illinois: The Dorsey sPress, 1965). In Chapter 6, "The Benedictine Rule", a translation is given of St. Benedict's Rule. In the section "On the Spirit of Silence" it states: "For speaking and teaching belong to the master; the disciple's part is to be silent and listen" (p. 146). 
Last der Regierung, an der ich schwer trage, aufgeben und mich in die Einsamkeit einer kleinen Zelle einschließen."82 Hildegard, who spent much of her life dedicated to monastic reform, was not obliging in her response to the abbess; rather, Hildegard felt it Sophia's duty to remain steadfast in her pastoral obligations and not flee to the solitary and passive life of an eremite:

Warum härmst du dich ab, so daß dein Geist wechselnden Wolken gleicht, die ein Sturm umherwirbelt, so daß es bald hell ist wie Licht, bald plötzlich sich verfinstert?...O Tochter, vor Gott hat es keinen Wert, daß du deine Bürde abwirfst und die Herde Gottes im Stich lässest, da du doch das Licht hast, um ihr zu leuchten und sie hinauszuführen auf die Weide. ${ }^{83}$ According to Hildegard's admonishing words, for the abbess to seek out the solitude of a hermitage for her own personal benefit would be neglecting the social responsibility entrusted to her by God. Living the life of a hermit would have no worth, keinen Wert, in the eyes of God as it would be harmful to the care of those entrusted to her. Again, as we saw earlier in Chapter II, Hildegard uses the Wolken motif to express a situation in flux that could result in a grim outcome. Hildegard compares the abbess' vacillation plaguing her spirit to wechselnden Wolken in a storm. At times the clouds separate and the light, God's will, shines through upon her spirit, bringing her into a state of euphoria and giving her strength to carry on. At other times, the clouds darken her spirit and

82 Bingen, Briefwechsel 210.

83 Bingen, Briefwechsel 211. 
she falls into a state of depression, causing her to fear her chosen path. Filled with the desire to cast aside her sacred Bürde she abandons those, die Herde Gottes, in her care. That the abbess is filled with the Living Light, she must recognize her responsibility to care for God's children "und sie hinausführen auf die Weide," lead them to the path of God.

A similar situation confronted Hildegard in an exchange of letters with the abbess Sophia of Kitzingen. Sophia turned to Hildegard, too, with the question of whether she should give up the burden of her office or continue on with it. In her response, Hildegard encourages the abbess to carry on with her pastoral responsibilities and to end the disparity that lies within her:

O Sophia, in geheimnisvoller Schau sage ich dir: Deine Seele werde durch Gott gestärkt, indem sie mit rechtem Seufzen Ihn anrührt. Gut ist es für dich, die Last der Arbeit zu tragen, die du in Gott auf dich genommen hast, vorausgesetzt, daß die Schafe die Ermahnung Gottes unter deiner Führung hören wollen. Wenn auch nur ein einziger Funke in ihnen aufleuchtet, so verlasse sie nicht, damit der Räuber sie nicht raubt. 84

If the abbess is successful in reaching just one person out of many, her work was worthwhile in the eyes of God. The abbess is responsible for the care of even that one person, so that he or she remains with God and is not stolen away by der Räuber, the evil in the world. Hildegard informs Sophia that to carry the burden of her divine work, a burden that she took

84 Bingen, Briefwechsel 205. 
upon herself, is good for her, "Gut ist es für dich." As long as there are those that will listen, the abbess' services are greatly needed; therefore, to lay aside her God-given duty would be harmful to the care and growth of His will on earth.

Thus, for Hildegard, whether it was in her deep affection for nature, her reverence for virginity or in the active responsibility for nurturing and caring for God's world, a feminine and compassionate side of God was manifested. In such a way, she felt that she was successful in bringing to life God's Word on earth, just as Christ had done.

Her masculine side

Hildegard maintained certain influential positions not normally held by a woman: preacher, correspondent, and political reformer. These positions were reserved mainly for the male clergy and laity. Beside making her mark in these predominantly male roles, Hildegard also expressed herself at times in a way that was quite masculine, using forceful words and catastrophically threatening statements. For a woman who supported a feminine theology in which the compassionate side of mankind could find its fullest expression, this other, more masculine, side seemed out of place and anything but compassionate. However, Hildegard saw that there was an equilibrium that must be met in all things and all situations. As in nature, there are times when calmness and solitude reign 
but at other times a more fierce and stalwart side takes over. If a more compassionate way was ineffective, at times she would resort to a "hell fire and brimstone" approach.

In her letters, her masculine side shines forth many times to threaten a lax Church and its clergy, as well as heads of state, with the wrath of God. If all else failed in her attempts to communicate a particular message to any one person, Hildegard would often close her letters with threats of catastrophic and apocalyse, comparable to those of the great seers in the Old Testament. Her messages stemmed from her visions which were said to have been influenced by a tenth-century monk's, Adso's, Treatise on the Antichrist 85 .

Although the emperor, Frederick I, had granted the Rupertsberg convent imperial protection, Hildegard attacked him for not supporting the officially elected pope, Alexander III. Instead, Frederick gave his support to the anti-pope, Victor IV, and later appointed his successor, Paschal III. Upon Paschal's death, he then appointed yet another anti-pope, Calsixtux III. Not one to hesitate in taking a stand on a political matter, Hildegard, who had staunchly opposed the dual papacy that existed throughout her lifetime, was deeply angered at the emperor's actions. At first, she maintained a modest composure in opposing the emperor's schismatic decisions and the first three of four letters she wrote to him bade him only warning. When the emperor refused to heed her warnings and continued to support the anti-pope, in her fourth and final letter to him, Hildegard inundated him with a series of catastrophic statements: 
Der da IST, spricht: Die Widerspenstigkeit zerstöre Ich, und den Widerstand derer, die Mir trotzen, zermalme Ich durch Mich selbst. Wehe, wehe, diesem bösem Tun der Frevler, die Mich verachten! Das höre, König, wenn du leben willst! Sonst wird Mein Schwert dich durchbohren! 86

Fearlessly, Hildegard, speaking in the name of God, der da IST, stood up against Barbarossa and castigated him with the fierce anger of God. In the above lines a more masculine and forceful side of God is expressed, more the God of the Old Testament. Rather than the gentle metaphors derived from nature, Hildegard uses here a more destructive and terrifying language, with such terms as zermalmen, zerstören and durchbohren. Instead of carrying the Zepter with Barmherzigkeit, God threatens to stab the emperor with His sword. Rather than offering salvation if he turns from his corrupt ways, God only threatens to destroy him if he doesn't comply. This is an interesting depiction of God as it reveals more a God of anger and destruction than a God of love and creation. In spite of the threatening words, the emperor did not comply with Hildegard's warnings and the dual papacy continued until 1177, two years before her death.

Hildegard shows once again a more masculine side in a letter to a former nun at the convent at Zwiefalten. In chastising the nun for falling away from God, for failing to uphold her sacred vow of virginity, Hildegard pours forth a series of catastrophic threats rather than consoling her with words of compassion:

86 Bingen, Briefwechsel 86. 
Bestimmt werden bald über dich die anderen Tage kommen, an denen deine Feinde dich von allen Seiten umzingeln werden - Tage, die nicht in deiner Gewalt sind. Deine zerquälte, elende Seele werden sie deinem Leibe entreißen und sie mit sich in das Land von Pech und Schwefel, in die von Tod und Todesdunkel erfüllte Unterwelt hinabziehen, wo keine Ordnung, sondern ewiger Schrecken haust, wo der Wurm nicht stirbt und das Feuer nicht erlischt. Dein Fleisch, das du jetzt der Wollust unterwirfst, werden sie fressen, wenn du nicht eilends in der Beichte vor das Antlitz des Herrn trittst und unter bitteren Tränen der Reue entsprechender Genugtuung die Verfehlerung deiner Jugend besserst. 87 In this rather gruesome series of images, Hildegard reproaches the nun for laying aside her fidelity to God, a fidelity she promised to Him when she originally took her vows as a nun. Rather than offering her the hope and love of a merciful and compassionate God, Hildegard attacks the nun with words of rage, warning her of apocalyptic consequences for her sinful behavior.

Nothing of the feminine face of God so often exemplified in Hildegard's works and letters appears here. Rather she seeks to instill the fear of God in the nun so as to hinder her from continuing on her path of doom and to encourage her to confess before God so as to better the Verfehlung, wrong-doings, of her youth. Why she chose to approach the nun in such a manner is not explained anywhere by Hildegard herself.

87 Bingen, Briefwechsel 215. 
Perhaps, at times, Hildegard too forgot the balance she vehemently sought to keep. Instead, as in the instance above, in a fury she lost sight of her original goal and threw the balance off. Just as the womanly can become an un-virtue if taken to extremes, so can the masculine.

Hildegard expresses her more masculine side in a letter we have already examined concerning the nobleman buried at the Rupertsberg cemetery. In order to attain the ideal balance she sought, between the expression of the masculine and feminine dimension of God, Hildegard applied all the means available to her. After having explored all (feminine) avenues to convince the prelates that the nobleman remain at the cemetery, Hildegard resorts to the use of catastrophic threats in hopes of reversing their decision 88 : "what she will not tolerate is any affront to that symphony of the heavenly and the earthly which had become consubstantial with her grasping of the truth." 89 Hildegard, now seventynine, strong-mindedly stands up to those who she feels had defied the will of God. In this case, the will of God supports her demand to retain the nobleman at the Rupertsberg churchyard and her opposition to the inaction of an interdict:

Diejenigen also, die der Kirche in bezug auf das Singen des Gotteslobes Schweigen auferlegen [durch ein Interdikt!], werden - da sie auf Erden das Unrecht begingen, Gott die Ehre

88 The decision to impose an interdict on her convent that would forbid, among other things, the singing of the liturgical music, that which was, for Hildegard, the ultimate means of bonding the earthly with the heavenly.

89 Dronke, Peter, Women Writers of the Middle Ages: A Critical Study of Texts from Perpetua (203) to Marguerite Porete (1310) (London: Cambridge University Press, 1984) 199. 
des Ihm zustehenden Lobes rauben - keine Gemeinschaft haben mit dem Lob der Engel im Himmel, wenn sie das nicht durch wahre Buße und demütige Genugtuung gutgemacht haben. Die also die Schlüssel des Himmels besitzen, sollen sich entschieden hüten zu öffnen, was zu schließen, und zu schließen, was zu öffnen ist. Denn das härteste Gericht wird über die Prälaten ergehen, wenn sie nicht, wie der Apostel sagt, ihr Vorsteheramt mit Sorgfalt führen. ${ }^{90}$

In a typically rhetorical style, Hildegard attempted, in the beginning of the letter and elsewhere, to explain her position by naming the reasons for burying the nobleman at the Rupertsberg cemetery. She also explained at length the need for the liturgical singing at her convent. As these attempts of explanation proved to be insufficient, Hildegard appeals, in the above passage, to that which was her last resort: catastrophically threatening words. In this way she could explicitly relay to the prelates the dire consequences that would befall them if they did not heed her words, words directly relayed to her from God.

In the above passage, Hildegard, as God's vessel, threatens the prelates, "Diejenigen also, die der Kirche in bezug auf das Singen des Gotteslobes Schweigen auferlegen...," with consequences that would be distressful to any religious person: to be shut off from the possibility of eternal life with God, "werden...keine Gemeinschaft haben mit dem Lob der Engel im Himmel." She continues by offering the prelates an alternative to avoid their damnation: Buße, repentance, and Genugtuung,

90 Bingen, Briefwechsel 240. 
reparation. She reminds them that their position is sacred in that they hold the key to the heavens and they must uphold it with the utmost care, Sorgfalt, and wisdom. If they fail do to so, she threatens, in the last line, that they will be handed down the härteste Gericht, the harshest punishment possible, once again drawing on threatening statements to resolve the discrepancy. Although this is not a passage as wonderfully or metaphorically vibrant as the earlier example, her intentions and approach are the same. Her statements here are threatening rather than merciful and compassionate. 


\section{Conclusion}

\section{The Success of Her Efforts}

Hildegard's purposes were humanitarian; she promoted human welfare, social and Church reform and the salvation of the people and the earth they lived on. Whereas some orders within the Church concentrated mainly on the salvation of the individual's soul in hope of eternal life, she believed in and concerned herself with the matters of this world, a world she felt worthy of care and love. She did not only believe in caring for this world but she felt it her moral and social responsibility to do so, a responsibility that went beyond the expectations of her order. For Hildegard this world and those who dwelled in it were the physical manifestation of God, a manifestation she saw as inherently feminine. According to her, there were various ways in which the feminine dimension of God was expressed in the world: in nature, in the status of virginity, in the Church and its clergy, and in mankind as a whole. All of these represent feminine aspects of God and thus Christians are responsible for their care and nurture. Hildegard felt that by successfully expressing the feminine nature inherent in God, the notion of salvation for mankind and the earthly world he dwelled in was very real and very possible.

Given her efforts and vast achievements, Hildegard was indeed successful in achieving the balance she sought on earth, a balance between 
the expression of the masculine and the feminine God. She practiced a feminine theology as far as one could in a patriarchal world and in a Church that did not always express the compassionate side of God. At times, she was caring and nurturing. Other times, if the voice of Wisdom failed, the forceful and paternal voice of God would be heard with the hellfire and brimstone tactics well known from the prophets of the Old Testament. Although her efforts were sometimes undermined or ignored by those above her - as in the exchange of letters with the prelates of Mainz or the emperor, Frederick I - or her customs challenged - as in the letter from the abbess of Tengswich - Hildegard stood strong, accrediting her strength to the Living Light that existed within her and found its expression through her weak, feminine vessel.

Hildegard achieved a success far beyond what she had anticipated, a success that has managed to reach across time into the 20th century. Just within the last decade there have been several books written about Hildegard von Bingen. Not only is she famous for her feminist ideas but also for the ideals she represented, ideals based on the feminine aspects of God that in their complete expression are salvational in nature. Perhaps her feminine theology is so appealing now because the world today is still in dire need of healing and care, in need of a maternal love to offset the rampant violence and destruction. This is a time that is masculine in its expression, forceful, angry and aggressive, and neglectful of the feminine as in the era in which Hildegard had once lived.

Hildegard was an individual filled with the love of God and in turn she felt it her duty to pour forth that love upon a world in need. If ever 
she came across as overbearing or demanding, I believe it was with her sacred position in mind, as God's vessel, that she thought such behavior on her part as valid. In earth, in mankind, in all of nature, she saw a dimension of God, a feminine dimension that found its expression uniquely in the world yet paralleled the God beyond this world. A powerful mystic, she felt a personal experience of God through her visions. What makes her truly extraordinary is her ability to describe these visions in words and images, and also to apply her Christian love and commitment so actively to the realities of her time. 


\section{Bibliography}

Anderson, Sherry Ruth and Patricia Hopkins. The Feminine Face of God:

The Unfolding of the Sacred in Women. New York: Bantam Books, 1991.

Bingen, Hildegard von. Briefwechsel. Trans. Adelgundis Führkötter. Salzburg: Otto Müller Verlag, 1965.

Bingen, Hildegard von. Wisse die Wege. Trans. Maura Bückeler. Salzburg: Otto Müller Verlag, 1981. Trans. of Scivias, 1141-1146. Block, R. Howard. Medieval Misogyny and the Invention of Western Romantic Love. Chicago: The University of Chicago Press, 1991. Bowie, Fiona and Oliver Davies, eds. Introduction. Hildegard of Bingen: An Anthology. Trans. Robert Carver. London: SPCK, 1992. 3-59. Brunn, Emilie Zum and George Epiney-Burgard. Women Mystics in Medieval Europe. New York: Paragon House, 1989.

Bynam, Caroline Walker. Holy Feast and Holy Fast. Berkeley: University of California Press, 1987.

Chicago, Judy. The Dinner Party. New York: Anchor Press, 1979. 76.

Donovan, Josephine. Feminist Theory: The Intellectual Traditions of American Feminism. New York: The Continuum Publishing Company, 1985.

Dronke, Peter. Women Writers of the Middle Ages: A Critical Study of Texts from Perpetus (203) to Marguerite Porete (1310). Cambridge: University Press, 1984.

Flanagan, Sabina. Hildegard of Bingen, 1098-1179: A Visionary Life London: Routledge, 1989. 
Fox, Matthew. Introduction. Illuminations of Hildegard von Bingen.

Trans. Bruce Hozeski. New Mexico: Bear and Company, 1985. 6-20.

Führkötter, Adelgundis. Preface: "Hildegard of Bingen's Wealth of

Scholarship." Scivias. Trans. Bruce Hozenski. New Mexico: Bear \& Company, 1986. xxv-xxxi.

Gottfried and Theodrich. Das Leben der Heiligen Hildegard. Trans.

Adelgundis Führkötter. Salzburg: Otto Müller Verlag, 1980.

Herwegen, Ildefons. Geleitwort. Wisse die Wege : Scivias. Trans.

Adelgundis Führkötter. Salzburg: Otto Müller Verlag, 1981. 11-14.

Kvastad, Nils Bjørn. Problems of Mysticism. Oslo: Scintilla Press, 1980. 740,230 .

Manchester, William. A World Lit Only By Fire. Boston: Little, Brown and Company, 1992.

Newman, Barbara. Sister of Wisdom. Berkeley: University of California Press, 1987.

O'Brien, Elmer S. J. Varieties of Mystic Experience. New York: Holt, Rinehart and Winston, 1964. 3-15.

Oehl, Wilhelm, ed. "Hildegard von Bingen." Deutsche Mystikerbriefe des Mittelalters: 1100-1550. Darmstadt: Wissenschaftliche Buchgesellschaft, 1972. 55-112.

Schipperges, Heinrich, ed. Einführung. Hildegard von Bingen. Olten:

Walter- Verlag AG, 1985. 8-34.

---, ed. Einführung. Welt und Mensch. Trans. Adelgundis Führkötter. Salzburg: Otto Müller Verlag, 1965. 9-17. 
Tarnas, Richard. Passion of the Western Mind. New York: Ballantine Books, 1991. 166.

The New Catholic Edition of the Holy Bible. New York: Catholic Book Publishing Company, 1951.

Underhill, Evelyn. Mysticism. New York: Image Books Doubleday, 1990.

---. The Mystics of the Church. New York: Schocken Books, 1964. 74-89, 133-151.

Warner, Marina. Alone of All Her Sex: The Myth and the Cult of the Virgin Mary. New York: Vintage Books, 1983.

Waterman, John T. A History of the German Language. Illinois:

Waveland Press, Inc., 1991.

Weeks, Andrew. German Mysticism from Hildegard of Bingen to Ludwig Wittgenstein. New York: State University of New York Press, 1993. 26-27,39-68.

White, Donald A. Medieval History: A Source Book. Illinois: The Dorsey Press, 1965. 